\title{
Relationship between Cleaner Production, Environmental Management, and Sustainable Product on Performance
}

\author{
Mahmood Zohoori \\ Master of Environmental \\ Management \\ Putra University of Malaysia \\ Birjand, Iran
}

\author{
Ali Ghani \\ Master of Business \\ Administration (MBA) \\ Industrial Management Institute \\ Birjand, Iran
}

\author{
Hojat Zakeri \\ Master of Environmental \\ Pollution \\ Islamic Azad University, \\ Science and Research Branch \\ Birjand,
}

\begin{abstract}
The current study attempts to link cleaner production and environmental management to sustainable product innovation and performance. Extant research only focused on financial performance while this study applied balanced scorecard (BSC) model for this purpose. As shown in the proposed framework of this study, cleaner production and environmental management can affect sustainable product innovation and thereby performance (financial, customer satisfaction, learning and growth, and internal process). It should be mentioned that the focal scope of this study is Iran.
\end{abstract}

Keywords: Cleaner Production, Environmental Management, Sustainable Product Innovation, Financial Performance, Customer Satisfaction, Learning and Growth, Internal Process, Iran)

\section{INTRODUCTION}

The global industrialization's intensification, explosion of population, new products development as well as excessive consumption and high population all contribute the economy to develop, however, led to serious ecosystems degradation environmentally. In this regard, the corporate environmentalism development that is a strategic business part, is considered as one of the most remarkable changes that started to take place in various markets in 21 th century.

Such actions within environmental context were proactive and began to be considered as innovations inherent in organizational competitive strategy that needed research and development of enduring products (Gelbmann and Hammerl, 2015; Severo et al., 2017).

There are many environmental practices which could be employed as the study of eco-design and product life cycle that has been a globally growing trend in various fields such as architecture, engineering as well as design. It has clue for developing new services, systems and products and also minimizing usage of nonrenewable resources to reduce their impacts environmentally (Chou, 2014; Kuo et al., 2016).

The Environmental Management (EM) and Cleaner Production (CP) practices are techniques which result in production process efficiency, employing the inputs and generating industrial waste. Such tools remarkably can help to Sustainable Product Innovation (SPI), because of using the national resources rationally and reducing the generated waste. Thus, sustainable product innovation is assumed as an opportunity for launching new products on market which can meet the imposed pressure by global society and legislation (Severo et al., 2017).

In Iran, during recent years, many new policies have been dispensed regarding the importance of green environment. However, they are not sufficient and there should be more investigation on it. More studies in this field will contribute Iran to grow as same as other developed countries. In addition, different companies attempt to comply themselves with global standards.

The recent research conducted by Sevro et al. (2017) states that cleaner production and environmental management affect sustainable product innovation and thereby financial performance. The current study believes that besides of financial performance, nonfinancial performance can be affected by cleaner production, environmental management and sustainable product innovation. The reason is 
that balanced scorecard (BSC) model of Kaplan and Norton (1997). According to this model performance has four perspectives including, financial, customer, learning and growth, and internal process. Besides, there are interactions between theses dimensions. Hence, this study aims to show that how cleaner production and environmental management affect sustainable product innovation and thereby company performance (financial and non-financial).

\section{LITERATURE REVIEW}

From environmental sustainability perspective, many surveys have been performed to understand the organizational and technical variables related to developing a sustainable product innovation (Elkington, 1999; Horbach, 2008; Lin et al., 2012; Marchi, 2012; Khalili and Duecker, 2013; Boons et al., 2013; Silverstre and Silve Neto, 2014).

Innovation could be as some alterations in services or products and how they are being offered or produced. Therefore, innovation is considered as implementation and development of new ideas that is a collective outcome (Van De Ven, 1986; Van De Ven et al., 1989; Garcia and Calantone, 2002). In this regard, innovating the sustainable products could be identified as introducing new or remarkably improved services and products by considering its characteristics or intended application of products produced by company previously (Balachandra and Friar, 1997).

It has to focus on environmental requirements in order to minimize employing the water, natural resources, materials, energy, improvements in environmental practices and production processes which reduce impacts on environment and minimizes production of pollutants and waste (Placet et al., 2005; Potts, 2010).

It should be considered that companies are able to optimize new product development and production process by using the environmental practices for example Cleaner Production methods (CP) that was presented by United Nations Industrial Development Organizations as well as United Nations Environment Programmes, hence organizations systematically can decrease their emissions and waste (Klipova and Staniskis, 2006; Hicks and Dietmar, 2007; Lukena et al., 2016).

The CP concept means those actions which enable an organization to qualify itself as an effective energy and raw material user within the production process, attempting to improve productivity which leads to improve in competitiveness and finally organizational performance (Severo et al., 2015)/ Here, CP technologies means employing and developing new techniques, methods, energy sources and material which reduce production waste and throughout life cycle of product (Dunn and Bush, 2001; Tseng et al., 2009; Yonga et al., 2016).

One of the integral programs of a company is Cleaner Production which presents interfering working teams with process of production which develops certain relationships with the suppliers and environmentally seek proper use of energy and natural resources, assuming productive requirements and reducing the environmental effects of the business activity. But, it would be a long-run strategy which can result in having competitive advantage over other rivals (Tseng et al., 2009; Bhupendraa and Sangleb, 2016; Lukena et al., 2016).

The CP approach has been employed in various segments and different sizes of organizations for embracing the production process efficiency that could help to having sustainable innovation (Boons et al., 2013; Silvestre and Silva Neto, 2014). CP should impact development process of new products via minimizing the usage of resources as well waste emission (Boons et al., 2013; Sivestre and Silva Neto, 2014; Kuo et al., 2016).

In a research conducted by Geng et al. (2010) it was revealed that increasing environmental issues in Chin made the regional Chinese governments to look for and promote $\mathrm{CP}$ such as coordination and measures of different stakeholders through offering financial 
support and through suggesting proper policies and performing training programs.

A study conducted by Van Hoff and Lyon (2013) on small and medium sized (SMEs) of Mexico, asserted that using the $\mathrm{CP}$ methods in emerging countries could help to having remarkable environmental and economic benefits across supply chains globally.

In addition, Massote and Santi (2013) explained that $\mathrm{CP}$ implementation is considered as an effective approach for obtaining eco-efficiency. Here, CP methods present viable alternatives for the companies via the implementation in process of production that contributes to reduction of waste, atmospheric emissions and wastewater as well as offering proper application of energy and raw materials and water consumption rationalization, so providing businesses environmental and economic benefits (Zeng et al., 2010; Ortolano et al., 2014; Van Hoof, 2014).

In 2013, Severo explained that metalmechanic cluster firms in Southern Brazil already have presented many product innovations in market by means of $\mathrm{CP}$ techniques. From total 333 studied companied, $25.8 \%$ of them applied CP techniques and occasioned benefits by $\mathrm{CP}$ might prevail for sustainable development of new services and products.

\subsection{Environmental management and sustainable product innovation}

The competitive landscape is transforming due to environmental sustainability quest as well as demand to changes in business to develop processes, products, business models and technologies and also rationally using the natural resources, treating and providing appropriately the generated waste in order to preserve the surrounding environment (Severo, 2013).

Within the organizational context, related environmental practices to processes and product development help to the sustainable development, offering the organizations more economic stability and environmental sustainability. Hence, companies can reduce environmental impacts through using the environmental management methods including: Effluent Treatment Plant (WWTP), Waste Management System (SGR), Environmental Management System (EMS) ISO 14001, Cleaner Production (CP), Life Cycle Analysis (LCA), Industrial Symbiosis (IS), Industrial Ecology (EI), Recycling, etc. (Anton et al., 2004; Sharma and Henriques, 2005; Marshall et al., 2005; Chertow, 2007; Darnall et al., 2008).

Regarding the related aspects to management, Marshall et al. (2005) asserted that Environmental Management process employs regulations and rules which impact proactive environmentalism.

In an organization, environmental management requires more effort in order to manage supplier and internal processes and also big initial investment due to it leads to improved performance financially (Darnall et al., 2008; Fenga et al., 2016).

In addition, previous studies demonstrated that organizations understand the necessity of environmental management not just for reducing the environmental impacts but also to achieve competitive advantage (York et al., 2003; Da Rosa et al., 2015). The methodologies for both organizational changes and environmental management increase environmental innovation. They form a type of innovation which helps to obtain sustainable development (Severo et al., 2017). In 2013, Youn et al studied 141 South Korean organizations that contextualize employing the environmental practices in order to promote improvement of services and products globally.

The other research performed by Jabbour et al., (2012) on total 75 Brazilian automotive industry firms, asserted that environmental management has positive impact on business operations performance, emphasizing on auto parts segment and also automotive components. A sustainable and innovative 
company simultaneously attempts to be effective economically, considering the environmental support capacity and that would not change resources availability in its ecosystems (Agyeman and Evans, 2004; Anton et al., 2004).

Thus, the probability to have environmental concerns in business innovation via proper practices environmentally could become important to keep future businesses in future. So, innovations attempt to improve production procedures, lower energy consumptions and lower costs will be critical for keeping the environmental sustainability (Nidumolu et al., 2009).

\subsection{Sustainable product innovation and financial performance}

Innovating sustainable products as well as financial performance is the main focus of many studies, specifically in contemporary organizations. As noted by Paladino (2007), financial performance concept emphasizes on profitability and quality of products and services to provide a certain return on investment (ROI), and also minimizing the operation costs and generating total performance and competitiveness. According to Przychodzen and Przychodzen (2015), generally, eco-innovations were known as "higher" return on quality and assets. Moreover, those firms which present ecoinnovations also were remarkably more performant and probably encounter with less financial risks and will have more "available" cash flow compared to conventional organizations.

An investigation has been conducted by Marchi (2012) in 6047 Spanish organizations and it was revealed that introducing the product innovations positively impact environment, through creating environmental innovations and through cooperation of research and development. But, related to environmental challenges, product innovation should be planned appropriately and should consider environmental issues for creating competitiveness. However, probability of failure in those projects which involve innovation could reach unfavorable proportions (Barbieri et al., 2010).

In addition, Cheng et al. (2014) asserted that sustainable innovation has strong impact on business performance in Taiwanese organizations. But, the findings demonstrated that managers should know about the positive relationship between sustainable innovation and the organizational performance.

\section{PROPOSED FRAMEWORK}

All above discussion there are reasonable relationships between cleaner production and sustainable product innovation and thereby financial performance. It is also true for environmental management. However, it seems that cleaner production and environmental management can affect nonfinancial performance. By considering BSC's perspectives we can improve the framework of Severo et al. (2017).

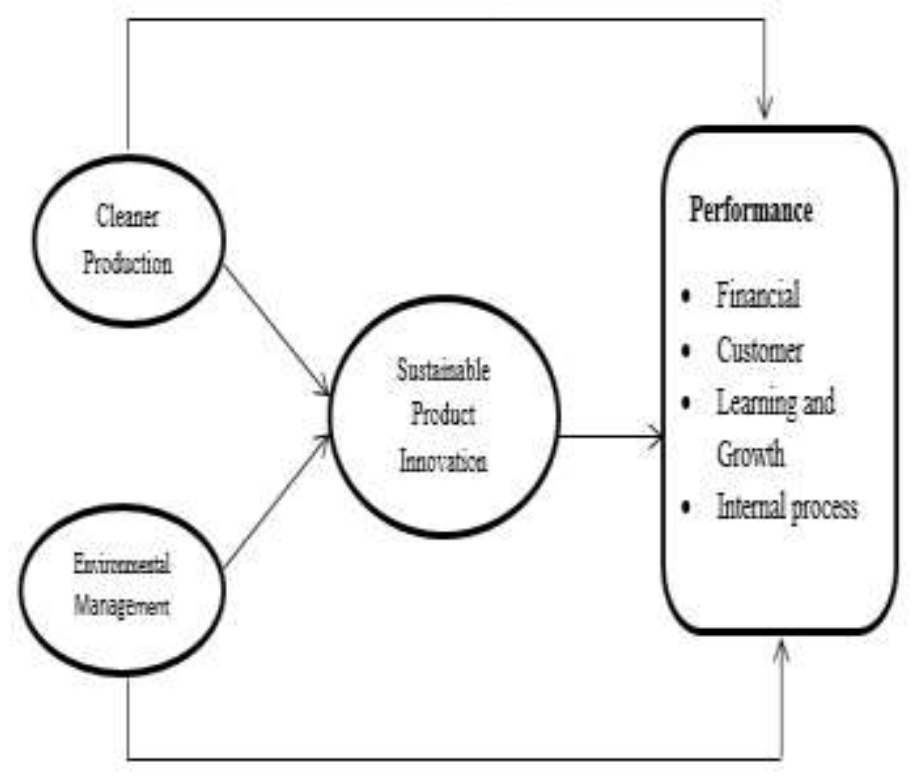

Figure 1: Proposed Framework of this study

As shown in Figure 1, cleaner production and environmental management can affect various perspectives of performance directly. Furthermore, current study believes that cleaner production and environmental management should be connected to each dimension of performance. There are several research conducted by Manafi and 
subramaniam (2015 a, b) which are concentrated on the vital role of knowledge in increasing innovation. They asserted that innovation can increase economic growth. As a result, the environmental management and also cleaner production include knowledge can be applied for innovation and thereby higher performance.

\section{CONCLUSION}

Extant research showed that cleaner production and environmental management have potential to affect sustainable product innovation. Besides, the impact of sustainable product innovation on financial performance was concentrated by Severo et al. (2017). Since according to BSC model there are four perspectives for performance, we could develop the proposed framework of Severo et al. (2017).

As a suggestion for future study, the proposed framework of this study (Figure 1) can be tested in different industries of Iran to highlight which dimensions of performance are being affected by the independent variable of this study. The results will be useful for policy makers in government as well. Besides, the proposed framework of this study has high potential to be applied for various industries in various countries.

\section{REFERENCES}

Agyeman, J., Evans, B., 2004. Just sustainability: the emerging discourse of environmental justice in Britain? Geogr. J. 170 (2), 155-164.

Anton, W.R.Q., Deltas, G., Khanna, M., 2004. Incentives for environmental selfregulation and implications for environmental performance. J. Environ. Econ. Manag. 48 (1), $632 \mathrm{e} 654$

Balachandra, R., Friar, J.H., 1997. Factors for Success in R\&D Projects and New Product Innovation: a Contextual Framework. IEEE Trans. Eng. Manage. N. J. 44 (3), 276-287.

Barbieri, J.C., Vasconcelos, I.F.G., Andreassi, T., Vasconcelos, F.V., 2010. Innovation and sustainability: new models and propositions. RAE 50 (2), 146-154.
Bhupendraa, K.V., Sangleb, S., 2016. Strategy to derive benefits of radical cleaner production, products and technologies: a study of Indian firms. J. Clean. Prod.126, 236247.

Boons, F., Montalvo, C., Quist, J., Wagner, M., 2013. Sustainable innovation, business models and economic performance: an overview. J. Clean. Prod. 45, 1-8.

Cheng, C.C.J., Yang, C-1., Sheu, C., 2014. The link between eco-innovation and business performance: a Taiwanese industry context. J. Clean. Prod. 64, 81-90.

Chertow, M.R., 2007. Unconvering industrial symbiosis. J. Industrial Ecol. New Haven 1 (1), 11-30.

Chou, J.-R., 2014. An ARIZ-based life cycle engineering model for eco-design. J. Clean. Prod. 66, 210-223.

Darnall, N., Jolley, G.J., Handfield, R., 2008. Environmental management systems and green supply chain management: complements for sustainability? Bus. Strategy Environ. 17 (1), $30-45$.

Da Rosa, F.S., Guesser, T., Hein, N., Pfitsche, E.D., Lunkes, R.J., 2015. Environmental impact management of Brazilian companies: analyzing factors that influence disclosure of waste, emissions, effluents, and other impacts. J. Clean. Prod. 96, 148-160.

Dunn, R.F., Bush, G.E., 2001. Using process integration for cleaner production. J. Clean. Prod. 9, 1-13.

Elkington, J., 1999. Cannibals with Forks. New Society, Canada.

Fenga, T., Caib, D.,Wangc, D., Zhanga, X., 2016. Environmental management systems and financial performance: the joint effect of switching cost and competitive intensity. J. Clean. Prod. 113, 781-791.

Garcia, R., Calantone, R., 2002. A critical look at technological innovation typology and innovativeness terminology: a literature review. J. Prod. Innovation Manag. 19 (2), 110-132.

Gelbmann, U., Hammerl, B., 2015. Integrative re-use systems as innovative business models for devising sustainable producteservice-systems. J. Clean. Prod. 97, 50-60. 
Geng, Y., Xinbei, W., Qinghua, Z., Hengxin, Z., 2010. Regional initiatives on promoting cleaner production in China: a case of Liaoning. J. Clean. Prod. 18,1502-1508.

Hicks, C., Dietmar, R., 2007. Improving cleaner production through the application of environmental management tools in China. J. Clean. Prod. 15, 395-408.

Horbach, J., 2008. Determinants of environmental Innovation e new evidence from German panel data sources. Res. Policy $37,163 \mathrm{e} 173$.

Kaplan, R.S. and Norton, D.P., 1997. Balanced ScorecardStrategien erfolgreich umsetzen.

Khalili, N.R., Duecker, S., 2013. Application of multi-criteria decision analysis in design of sustainable environmental management system framework. J. Clean. Prod. 47, 188-198.

Kliopova, I., Staniskis, J.K., 2006. The evaluation of cleaner production performance in Lithuanian industries. J. Clean. Prod. 14, 1561-1575.

Kuo, T.-C., Smith, S., Smith, G.C., Huang, S.H., 2016. A predictive product attribute driven eco-design process using depth-first search. J. Clean. Prod. 112 (4), 3201-3210.

Lin, R.J., Tan, K.H., Geng, Y., 2012. Market demand, green product innovation, and firm performance: evidence from Vietnam motorcycle industry. J. Clean. Prod. 30, 1-7.

Lukena, R.A., Van Berkelb, R., Leuenbergerc, H., Schwagerb, P., 2016. A 20-year retrospective of the national cleaner production centres programme. J. Clean. Prod. 112, 11651174.

Manafi, M. and Subramaniam, I.D., 2015a. The Role of the Perceived Justice in the Relationship between Human Resource Management Practices and Knowledge Sharing: A Study of Malaysian Universities Lecturers. Asian Social Science, 11(12), p.131.

Manafi, M. and Subramaniam, I.D., 2015b. Relationship between Human Resources Management Practices, Transformational Leadership, and Knowledge Sharing on Innovation in Iranian Electronic Industry. Asian Social Science, 11(10), p.358.
Marchi, V., 2012. Environmental innovation and R\&D cooperation: empirical evidence from Spanish manufacturing firms. Res. Policy 41, 614-623.

Marshall, R.S., Cordano, M., Silverman, M., 2005. Exploring individual and institutional drivers of proactive environmentalism in the US wine industry. Bus. Strategy Environ. 14 (2), 92-109.

Massote, C.H.R., Santi, A.M.M., 2013. Implementation of a cleaner production program in a Brazilian wooden furniture factory. J. Clean. Prod. 46, 89-97.

Nidumolu, R., Prahalad, C.K., Rangaswami, M.R., 2009. Why sustainability is now the key driver of innovation? Harv. Bus. Rev. 87 (9), 57-64.

Ortolano, L., Sanchez-Triana, E., Afzal, J., Laiq Ali, C., Rebellon, S.A., 2014. Cleaner production in Pakistan's leather and textile sectors. J. Clean. Prod. 68, 121-129.

Placet, M., Anderson, R., Fowler, K.M., 2005. Strategies for sustainability: innovation and customization are critical, studies for the cement industry and state of Arizona reveal. ResearchTechnologyManagement 48 (5), 32-41.

Paladino, A., 2007. Investigating the drivers of innovation and new product success: a comparison of strategic orientations. J. Prod. Innovation Manag. 24, 534-553.

Przychodzen, J., Przychodzen, W., 2015. Relationships between eco-innovation and financial performance: evidence from publicly traded companies in Poland and Hungary. J. Clean. Prod. 90, 253-263.

Potts, T., 2010. The natural advantage of regions: linking sustainability, innovation, and regional development in Australia. J. Clean. Prod. 18 (8), 713-725.

Severo, E.A., 2013. Innovation and Environmental Sustainability in the Automotive Companies of the Metal Mechanic Cluster Located in the Serra Gaúcha. Thesis (Doctorate in Business Administration). Postgraduate Programme Doctorate in Business Administration, Pontificate Catholic University of Rio Grande do Sul/University of Caxias do Sul (accessed in April 2016). https://repositorio.ucs.br/jspui/bitstream/11338/676/1/Tese\%2 0Eliana\%20Andrea\%20Severo.pdf 


\section{International Journal of Science and Engineering Applications \\ Volume 6 Issue 01, 2017, ISSN-2319-7560 (Online)}

Severo, E.A., Guimaraes, J.C.F., Dorion, E.C.H., Nodari, C.H., 2015. Cleaner production, environmental sustainability and organizational performance: an empirical study in the Brazilian metal-mechanic industry. J. Clean. Prod. 96, 118125.

Severo, E. A., de Guimarães, J. C. F., \& Dorion, E. C. H. (2017). Cleaner production and environmental management as sustainable product innovation antecedents: A survey in Brazilian industries. Journal of Cleaner Production, 142, 8797.

Sharma, S., Henriques, I., 2005. Stakeholder influences on sustainability practices in the Canadian forest products industry. Strategic Manag. J. 26 (2), 159-180.

Silvestre, B.S., Silva Neto, R., 2014. Are cleaner production innovations the solution for small mining operations in poor regions? the case of Padua in Brazil. J. Clean. Prod. 84, 809817.

Tseng, M.L., Lin, Y.H., Chiu, A.S.F., 2009. Fuzzy AHPbased study of cleaner production implementation in Taiwan PWB manufacturer. J. Clean. Prod. 17 (14), 1249-1256.

Van De Ven, A.H., 1986. Central problems in the management of innovation. Manag. Sci. 32 (5), 590-607.

Van De Ven, A.H., Angle, H.L., Poole, M.S., 1989. Research on the Management of Innovation: the Minnesota Studies. Harper \& Row, New York.

Van Hoff, B., Lyon, T.P., 2013. Cleaner production in small firms taking part in Mexico's Sustainable Supplier Program. J. Clean. Prod. 41, 270-282.

Van Hoof, B., 2014. Organizational learning in cleaner production among Mexican supply networks. J. Clean. Prod. 64, 115-124.

Yonga, J.Y., Klemesa, J.J., Varbanova, P.S., Huisinghb, D., 2016. Cleaner energy for cleaner production: modelling, simulation, optimisation and waste management. J. Clean.

Prod. 111, 1-16.

York, R., Rosa, E.A., Dietz, T., 2003. Footprints on the earth: the environmental consequences of modernity. Am. Sociol. Rev. 68 (2), 279-300.
Zeng, S.X., Meng, X.H., Yin, H.T., Tamb, C.M., Sun, L., 2010. Impact of cleaner production on business performance.

J. Clean. Prod. 18, 975-983. 